\title{
Urinary tract infection in female in Kirkuk city, Iraq: Association between risk factors and bacterial type
}

\author{
Abdulghani Mohamed Alsamarai ${ }^{1}$, Shler Ali Khorshed ${ }^{2}$, Hajer Ali $^{3}$ \\ ${ }^{1}$ Departments of Medicine and Microbiology, Tikrit University College of Medicine, Tikrit, Iraq, ${ }^{2}$ Department of Biology, \\ Essential College of Education, Kirkuk Education Authority, Kirkuk, Iraq, ${ }^{3}$ Department of Biology, College of Education for \\ Pure Sciences, Kirkuk University, Kirkuk, Iraq
}

Corresponding author: Prof. Abdulghani Mohamed Alsamarai, E-mail: galsamarrai@yahoo.com

\begin{abstract}
Background: Urinary tract infection is the most common community and hospital bacterial infection and characterized by high rate of treatment failure and recurrences. Aim: to determine the association between risk factors and bacterial type. Materials and Methods: A prospective cross-sectional study conducted during the period from lst of June 2015 to the end of January 2016. The population included in the study are 563 women, of them 425 (75.5\%) were outpatients, and 138 (24.5\%) were inpatients. Their age range between 18 and 80 years, with a mean age of $33.59 \pm 15.29$ years. Urine samples were immediately cultured on blood agar and MacConkey's agar by spread plate technique. Bacterial colonies with different morphology were selected, purified and identified according to their biochemical characteristics using conventional standard methods. Results: Mean age was significantly $(\mathrm{F}=5.14, \mathrm{P}=0.002)$ different in relation to bacterial type. Women infected with E. coli were with higher mean age (37.84 year), followed by those infected with Staphylococcus aureus (31.97 year), then Klebsiella pneumonia (28.76 year) and Proteus mirabilis (28.50 year). BMI mean value was significantly $(\mathrm{F}=6.33, \mathrm{P}=0.000)$ different in women infected with different bacteria and higher value was in those infected with E. coli (26.15), while it was about the same in those infected with Staphylococcus aureus (24.6), then Klebsiella pneumonia (24.9 year) and Proteus mirabilis (24.1). Pus cell scale mean value was significantly $(\mathrm{F}=6.67, \mathrm{p}=0.000)$ higher in cases infected with $\mathrm{E}$. coli (2.04), while 1.77 in Staphylococcus aureus, infected cases, 1.15 in women infected with Klebsiella pneumonia and 1.33 in those infected with Proteus mirabilis. Conclusion: Age, BMI, pus cells scale, and education levels were significantly associated with bacterial type.
\end{abstract}

Key words: Urinary tract infection; Kirkuk; E. coli; Staphylococcus aureus; Klebsiella pneumonia; Proteus mirabilis

\section{INTRODUCTION}

Urinary tract infection is the most common community and hospital bacterial infection encountered in human population for all age groups [1]. The prevalence of UTI was higher with in female as compared to male and increased in both gender with age [2]. Enterobacteriaceae form the common etiologic agents of primary and recurrent urinary tract infection [3]. However, E. coli still form the common etiological agent of urinary tract infections in both genders [2]. The problems in the management of urinary tract infections are attributed to factors related to host and those related to the causative agents of urinary tract infections (4). The most important factor related to causative agents of urinary tract infection that lead to treatment failure and recurrent infection was the emergence of resistance to antibiotics [3-8]. Thus this study was conducted to determine the association between risk factors and bacterial type.

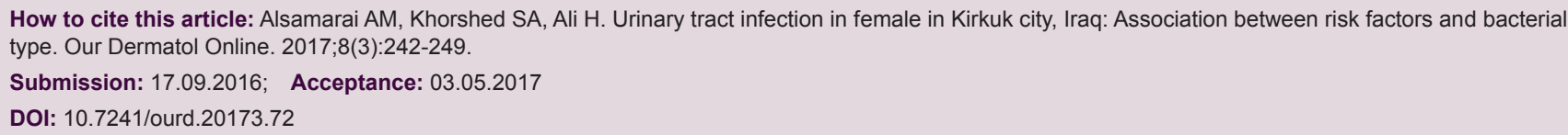




\section{MATERIALS AND METHODS}

\section{Study Design}

A prospective cross-sectional study conducted during the period from 1st of June 2015 to the end of January 2016. The population included in the study is 563 women, of them 425 (75.5\%) were outpatients and $138(24.5 \%)$ were inpatients. Their age range between 18 and 80 years, with a mean age of $33.59 \pm 15.29$ years. The study proposal was approved by the Ethical Committee of College of Science, Tikrit University and verbal informed consent taken from each woman before enrolment in the study.

\section{Bacterial Isolation}

Urine samples were centrifuged and sediments immediately cultured on blood agar and MacConkey's agar by spread plate technique. Bacterial colonies with different morphology were selected, purified and identified according to their biochemical characteristics using conventional standard methods [9].

\section{Statistical Analysis}

Analysis performed using SPSS (version20). The data presented as percentages, mean value and standard deviation. Chi square used to calculate significance for frequency, while t test used to determine significance in mean difference. $P$ value of $<0.05$ regarded significant.

\section{RESULTS}

Mean age was significantly $(\mathrm{F}=5.14, \mathrm{P}=0.002)$ different in relation to bacterial type. Women infected with E. coli were with higher mean age (37.84 year), followed by those infected with Staphylococcus aureus (31.97 year), then Klebsiella pneumonia (28.76 year) and Proteus mirabilis (28.50 year) (Table 1 ). BMI mean value was significantly $(\mathrm{F}=6.33, \mathrm{P}=0.000)$ different in women infected with different bacteria and higher value was in those infected with E. coli (26.15), while it was about the same in those infected with Staphylococcus aureus (24.6), then Klebsiella pneumonia (24.9 year) and Proteus mirabilis (24.1) (Table 1).

Pus cell scale mean value was significantly $(\mathrm{F}=6.67$, $\mathrm{p}=0.000)$ higher in cases infected with E. coli (2.04), while 1.77 in Staphylococcus aureus, infected cases, 1.15 in women infected with Klebsiella pneumonia and 1.33 in those infected with Proteus mirabilis (Table 1).
Table 1: Bacterial type in regard to age, BMI and pus cell mean values

\begin{tabular}{|c|c|c|c|c|}
\hline Variable & Bacterial type & $\mathbf{N}$ & Mean & Std. Deviation \\
\hline \multirow[t]{5}{*}{ Age } & E. coli & 135 & 37.84 & 17.47 \\
\hline & Staph aureus & 41 & 31.98 & 14.01 \\
\hline & Klebsiella pneumonia & 34 & 28.76 & 11.18 \\
\hline & Proteus mirabilis & 24 & 28.50 & 11.68 \\
\hline & Total & 234 & 34.54 & 16.02 \\
\hline \multirow[t]{5}{*}{ BMI } & E. coli & 135 & 26.15 & 2.95 \\
\hline & Staph aureus & 41 & 24.61 & 3.06 \\
\hline & Klebsiella pneumonia & 34 & 24.94 & 1.97 \\
\hline & Proteus mirabilis & 24 & 24.11 & 2.16 \\
\hline & Total & 234 & 25.49 & 2.87 \\
\hline \multirow[t]{5}{*}{ Pus Cell } & E. coli & 135 & 2.04 & 1.07 \\
\hline & Staph aureus & 41 & 1.76 & 1.30 \\
\hline & Klebsiella pneumonia & 34 & 1.15 & 1.23 \\
\hline & Proteus mirabilis & 24 & 1.33 & 1.27 \\
\hline & Total & 233 & 1.79 & 1.20 \\
\hline
\end{tabular}

Age $F=5.136, P=0.002 ; B M I F=6.328, P=0.000 ;$ Pus cell $F=6.672, P=0.000$

E. coli predominantly isolated from married women $(85.2 \%, 115 / 135)$, while in single women it was isolated from 14.8\% (20/135). Also, 75.6\% (31/41) of Staphylococcus aureus was isolated from married women and $24.4 \%(10 / 41)$ was isolated from single women. In addition, $70.6 \%$ (24/34) of Klebsiella pneumonia was isolated from married women, while $29.4 \%$ (10/34) was isolated from single women. Furthermore, $79.2 \%$ (19/24) of Proteus mirabilis was isolated from married women and 11.1 (5/24) \% was isolated from single women, Table 2. The overall frequency distribution of the 4 bacteria between married and single women was not with significant $(\mathrm{Chi}=4.71, \mathrm{P}>0.05)$ differences (Table 2).

The frequency rate of UTI aetiology for the four isolated bacteria is no significantly different (Chi=27.29, $\mathrm{P}>0.05)$ in relation to child number. The overall isolation rate not demonstrates a specific pattern in regards to child number. E. coli higher isolation rate was from nulliparous (24.4\%), while the lower isolation was from women with 7 children (1.5\%). Staphylococcus aureus isolation rate was $31.7 \%$ from nulliparous and lowest isolation was from women with 6 children (2.4\%). Klebsiella pneumonia and Proteus mirabilis lower isolation rate was from women with 7 child, while higher isolation rate was from nulliparous (Table 3).

There was no significant $(\mathrm{Chi}=8.43, \mathrm{P}>0.05)$ differences in the isolation of the 4 bacteria in relation to delivery method. However, E. coli was predominantly isolated from women with vaginal delivery (57\%), followed by non-pregnant women $(25.2 \%)$ and lower rate was in those delivered by caesarean section (17.8\%). Staphylococcus aureus, K. pneumonia and 
Table 2: Bacterial type in regard to marital status

\begin{tabular}{|c|c|c|c|c|c|}
\hline \multirow[t]{2}{*}{ Marital status } & \multicolumn{4}{|c|}{ Bacteria } & \multirow[t]{2}{*}{ Total } \\
\hline & E. coli & Staph aureus & K. pneumonia & Proteus mirabilis & \\
\hline \multicolumn{6}{|l|}{ Married } \\
\hline Count & 115 & 31 & 24 & 19 & 189 \\
\hline$\%$ within mar status & 60.8 & 16.4 & 12.7 & 10.1 & 100.0 \\
\hline$\%$ within bacteria & 85.2 & 75.6 & 70.6 & 79.2 & 80.8 \\
\hline$\%$ of total & 49.1 & 13.2 & 10.3 & 8.1 & 80.8 \\
\hline \multicolumn{6}{|l|}{ Single } \\
\hline Count & 20 & 10 & 10 & 5 & 45 \\
\hline$\%$ within mar status & 44.4 & 22.2 & 22.2 & 11.1 & 100.0 \\
\hline$\%$ within bacteria & 14.8 & 24.4 & 29.4 & 20.8 & 19.2 \\
\hline$\%$ of total & 8.5 & 4.3 & 4.3 & 2.1 & 19.2 \\
\hline \multicolumn{6}{|l|}{ Total } \\
\hline Count & 135 & 41 & 34 & 24 & 234 \\
\hline$\%$ within mar status & 57.7 & 17.5 & 14.5 & 10.3 & 100.0 \\
\hline$\%$ within bacteria & 100.0 & 100.0 & 100.0 & 100.0 & 100.0 \\
\hline$\%$ of total & 57.7 & 17.5 & 14.5 & 10.3 & 100.0 \\
\hline
\end{tabular}

$\mathrm{Chi}=4.71, \mathrm{P}>0.05$

Proteus mirabilis show the pattern of isolation rate of E. coli. In addition, the overall isolation rate was $56 \%$ in women with vaginal delivery, $29.9 \%$ in non-pregnant and $14.1 \%$ in women with caesarean section delivery method (Table 4).

The isolation rate was lower in women with history of operation for E. coli(12.6\%), Staphylococcus aureus (9.8\%), K. pneumonia(3\%) and Proteus mirabilis (12.5\%). However, this low rate of isolation may be due to small size number of women with history of operation in our study cohort. The frequency distribution pattern for the four bacteria was not significantly (Chi $=2.65, \mathrm{P}>0.05)$ different in relation to operation history (Table 5 ).

There was a significant $(\mathrm{Chi}=18.25, \mathrm{P}=0.032)$ differences between the four isolated bacteria in relation to education level. The predominant rate of isolation for the 4 bacteria was from women higher education level, however, the lowest isolation rate was from women with secondary education level for E. coli (11.1\%), primary education level for Staphylococcus aureus $(7.3 \%)$ and K. pneumonia(5.9\%), and illiterate (4.2\%) for Proteus mirabilis (Table 6).

E. coli, Staphylococcus aureus, K. pneumonia and Proteus mirabilis were not significantly $(\mathrm{Chi}=13.72$, $\mathrm{P}>0.05)$ different in their isolation rates in relation to economic status. All the four bacteria were predominantly ( $\geq 1 / 2$ of the isolates) isolated from women with average economic level, followed by those with good economic level. This may be due to samples driven effect as 501 from 563 of the study population were from average and good economic level (Table 7).
The four type isolated bacteria were not significantly $(\mathrm{Chi}=0.43, \mathrm{P}>0.05)$ different in relation to hospital setting and all bacteria types were predominantly $(70.7 \%-76.5 \%)$ isolated from outpatient women (Table 8).

\section{DISCUSSION}

The type of UTI causative bacteria was significantly correlated to mean age of women with positive culture. Women infected with E. coli were with higher mean age (37.84 year), followed by those infected with Staphylococcus aureus (31.97 year), then Klebsiella pneumonia (28.76 year) and Proteus mirabilis (28.50 year). Amiri et al [10], Iran, found that E. coli account as a cause of UTI for more than $1 / 2$ of the cases and $86.9 \%$ of their study population were in the age of $>25$ years and this indicated that older age women are more prone to get UTI due to E. coli. In addition, Salman et al (11), Diyala, Iraq, reported that E. coli caused UTI in women and $78 \%$ of them are with age of $<30$ years. However, the above data was contracted with the finding of Njunda et al [12] as they found high rate of UTI in diabetic women with age of $>40$ years.

Colonization of urinary tract with E. coli was enhanced in postmenopausal women estrogen reduction which attributed to vaginal muscle weakness, increased vaginal $\mathrm{pH}$ and decrease in vaginal flora [13]. BMI mean value was significantly different in women infected with different bacteria and higher value was in those infected with E. coli, while it was about the same in those infected with Staphylococcus aureus, Klebsiella pneumonia and Proteus mirabilis. 


\section{www.odermatol.com}

Table 3: Bacterial type in regard to child number

\begin{tabular}{|c|c|c|c|c|c|}
\hline \multirow[t]{2}{*}{ Child number } & \multicolumn{4}{|c|}{ Bacteria } & \multirow[t]{2}{*}{ Total } \\
\hline & E. coli & Staph aureus & K. pneumonia & Proteus mirabilis & \\
\hline \multicolumn{6}{|l|}{0.00} \\
\hline Count & 33 & 13 & 14 & 9 & 69 \\
\hline$\%$ within child number & 47.8 & 18.8 & 20.3 & 13.0 & 100.0 \\
\hline$\%$ within bacteria & 24.4 & 31.7 & 41.2 & 37.5 & 29.5 \\
\hline$\%$ of total & 14.1 & 5.6 & 6.0 & 3.8 & 29.5 \\
\hline \multicolumn{6}{|l|}{1.00} \\
\hline Count & 10 & 7 & 6 & 6 & 29 \\
\hline$\%$ within child number & 34.5 & 24.1 & 20.7 & 20.7 & 100.0 \\
\hline$\%$ within bacteria & 7.4 & 17.1 & 17.6 & 25.0 & 12.4 \\
\hline$\%$ of total & 4.3 & 3.0 & 2.6 & 2.6 & 12.4 \\
\hline \multicolumn{6}{|l|}{2.00} \\
\hline Count & 21 & 3 & 4 & 3 & 31 \\
\hline$\%$ within child number & 67.7 & 9.7 & 12.9 & 9.7 & 100.0 \\
\hline$\%$ within bacteria & 15.6 & 7.3 & 11.8 & 12.5 & 13.2 \\
\hline$\%$ of total & 9.0 & 1.3 & 1.7 & 1.3 & 13.2 \\
\hline \multicolumn{6}{|l|}{3.00} \\
\hline Count & 25 & 6 & 2 & 1 & 34 \\
\hline$\%$ within child number & 73.5 & 17.6 & 5.9 & 2.9 & 100.0 \\
\hline$\%$ within bacteria & 18.5 & 14.6 & 5.9 & 4.2 & 14.5 \\
\hline$\%$ of total & 10.7 & 2.6 & 0.9 & 0.4 & 14.5 \\
\hline \multicolumn{6}{|l|}{4.00} \\
\hline Count & 19 & 4 & 5 & 2 & 30 \\
\hline$\%$ within child number & 63.3 & 13.3 & 16.7 & 6.7 & 100.0 \\
\hline$\%$ within bacteria & 14.1 & 9.8 & 14.7 & 8.3 & 12.8 \\
\hline$\%$ of total & 8.1 & 1.7 & 2.1 & 0.9 & 12.8 \\
\hline \multicolumn{6}{|l|}{5.00} \\
\hline Count & 18 & 4 & 2 & 2 & 26 \\
\hline$\%$ within child number & 69.2 & 15.4 & 7.7 & 7.7 & 100.0 \\
\hline$\%$ within bacteria & 13.3 & 9.8 & 5.9 & 8.3 & 11.1 \\
\hline$\%$ of total & 7.7 & 1.7 & 0.9 & 0.9 & 11.1 \\
\hline \multicolumn{6}{|l|}{6.00} \\
\hline Count & 7 & 1 & 1 & 1 & 10 \\
\hline$\%$ within child number & 70.0 & 10.0 & 10.0 & 10.0 & 100.0 \\
\hline$\%$ within bacteria & 5.2 & 2.4 & 2.9 & 4.2 & 4.3 \\
\hline$\%$ of total & 3.0 & 0.4 & 0.4 & 0.4 & 4.3 \\
\hline \multicolumn{6}{|l|}{7.00} \\
\hline Count & 2 & 3 & 0 & 0 & 5 \\
\hline$\%$ within child number & 40.0 & 60.0 & 0.0 & 0.0 & 100.0 \\
\hline$\%$ within bacteria & 1.5 & 7.3 & 0.0 & 0.0 & 2.1 \\
\hline$\%$ of total & 0.9 & 1.3 & 0.0 & 0.0 & 2.1 \\
\hline \multicolumn{6}{|l|}{ Total } \\
\hline Count & 135 & 41 & 34 & 24 & 234 \\
\hline$\%$ within child number & 57.7 & 17.5 & 14.5 & 10.3 & 100.0 \\
\hline$\%$ within bacteria & 100.0 & 100.0 & 100.0 & 100.0 & 100.0 \\
\hline$\%$ of total & 57.7 & 17.5 & 14.5 & 10.3 & 100.0 \\
\hline
\end{tabular}

The mean value of pus cell scale was significantly higher in cases infected with E. coli, followed by in those infected with Staphylococcus aureus, Proteus mirabilis, and Klebsiella pneumonia. This variation in pus cell scale between cases infected with different bacterial types could be due IBC and QIR formation and the difference in their virulence factors.

E. coli, Staphylococcus aureus, Klebsiella pneumonia and Proteus mirabilis were predominantly isolated from married women than from single women, but there were no significant differences in frequency distribution when analysis performed on bacterial type strata. In addition, the infection was lower in single than in married women due to that intercourse in married women was a risk factor for UTI [14-18].

Child number was not significantly influence bacterial type in women urinary tract infection. The overall isolation rate not demonstrates a specific pattern in 
www.odermatol.com

Table 4: Delivery method influence on bacterial type

\begin{tabular}{|c|c|c|c|c|c|}
\hline \multirow[t]{2}{*}{ Delivery method } & \multicolumn{4}{|c|}{ Bacteria } & \multirow[t]{2}{*}{ Total } \\
\hline & E. coli & Staph aureus & K. pneumonia & Proteus mirabilis & \\
\hline \multicolumn{6}{|l|}{ No pregnancy } \\
\hline Count & 34 & 13 & 14 & 9 & 70 \\
\hline$\%$ within del method & 48.6 & 18.6 & 20.0 & 12.9 & 100.0 \\
\hline$\%$ within bacteria & 25.2 & 31.7 & 41.2 & 37.5 & 29.9 \\
\hline$\%$ of total & 14.5 & 5.6 & 6.0 & 3.8 & 29.9 \\
\hline \multicolumn{6}{|l|}{ Vaginal } \\
\hline Count & 77 & 24 & 19 & 11 & 131 \\
\hline$\%$ within del method & 58.8 & 18.3 & 14.5 & 8.4 & 100.0 \\
\hline$\%$ within bacteria & 57.0 & 58.5 & 55.9 & 45.8 & 56.0 \\
\hline$\%$ of total & 32.9 & 10.3 & 8.1 & 4.7 & 56.0 \\
\hline \multicolumn{6}{|l|}{ Caesarean } \\
\hline Count & 24 & 4 & 1 & 4 & 33 \\
\hline$\%$ within del method & 72.7 & 12.1 & 3.0 & 12.1 & 100.0 \\
\hline$\%$ within bacteria & 17.8 & 9.8 & 2.9 & 16.7 & 14.1 \\
\hline$\%$ of total & 10.3 & 1.7 & 0.4 & 1.7 & 14.1 \\
\hline \multicolumn{6}{|l|}{ Total } \\
\hline Count & 135 & 41 & 34 & 24 & 234 \\
\hline$\%$ within del method & 57.7 & 17.5 & 14.5 & 10.3 & 100.0 \\
\hline$\%$ within bacteria & 100.0 & 100.0 & 100.0 & 100.0 & 100.0 \\
\hline$\%$ of total & 57.7 & 17.5 & 14.5 & 10.3 & 100.0 \\
\hline
\end{tabular}

Table 5: Operation history influence on bacterial type

\begin{tabular}{|c|c|c|c|c|c|}
\hline \multirow[t]{2}{*}{ Operation history } & \multicolumn{4}{|c|}{ Bacteria } & \multirow[t]{2}{*}{ Total } \\
\hline & E. coli & Staph aureus & K. pneumonia & Proteus mirabilis & \\
\hline \multicolumn{6}{|l|}{ No } \\
\hline Count & 118 & 37 & 32 & 21 & 208 \\
\hline$\%$ within operation & 56.7 & 17.8 & 15.4 & 10.1 & 100.0 \\
\hline$\%$ within bacteria & 87.4 & 90.2 & 97.0 & 87.5 & 89.3 \\
\hline$\%$ of total & 50.6 & 15.9 & 13.7 & 9.0 & 89.3 \\
\hline \multicolumn{6}{|l|}{ Yes } \\
\hline Count & 17 & 4 & 1 & 3 & 25 \\
\hline$\%$ within operation & 68.0 & 16.0 & 4.0 & 12.0 & 100.0 \\
\hline$\%$ within bacteria & 12.6 & 9.8 & 3.0 & 12.5 & 10.7 \\
\hline$\%$ of total & 7.3 & 1.7 & 0.4 & 1.3 & 10.7 \\
\hline \multicolumn{6}{|l|}{ Total } \\
\hline Count & 135 & 41 & 33 & 24 & 233 \\
\hline$\%$ within operation & 57.9 & 17.6 & 14.2 & 10.3 & 100.0 \\
\hline$\%$ within bacteria & 100.0 & 100.0 & 100.0 & 100.0 & 100.0 \\
\hline$\%$ of total & 57.9 & 17.6 & 14.2 & 10.3 & 100.0 \\
\hline
\end{tabular}

Chi=2.65, P>0.05

regards to child number for the all 4 isolated bacterial genus. E. coli higher isolation rate was from nulliparous and was 16 times than the lower isolation rate from women with 7 children. Staphylococcus aureus isolation rate was 13 times from nulliparous than the lowest isolation from women with 6 children. Klebsiella pneumonia and Proteus mirabilis higher isolation rate was from nulliparous and not isolated from women with 7 child.

There were no significant differences in the isolation of the 4 bacteria in relation to delivery method. However, E. coli was predominantly isolated from women with vaginal delivery $(76.2 \%)$ and $25.8 \%$, however, this not consistent to that reported by Amiri et al for Iran, they reported that E. coli was isolated from $51.7 \%$ of women with vaginal delivery and from $48.3 \%$ from those with caesarean section. Staphylococcus aureus isolation rate was $85.7 \%$ in women delivered vaginally, while a rate of $80 \%$ was reported for Iran. K. pneumonia isolation rate was $95 \%$ from women delivered vaginally and this is much higher to that for Iran (28\%). Proteus mirabilis show isolation rate of $73.3 \%$ and was about similar to that of Iran [10].

Previous history of operation not influence the type of bacterial isolation, however, the isolation rate was 
www.odermatol.com

Table 6: Education level influence on bacterial type

\begin{tabular}{|c|c|c|c|c|c|}
\hline \multirow[t]{2}{*}{ Education level } & \multicolumn{4}{|c|}{ Bacteria } & \multirow[t]{2}{*}{ Total } \\
\hline & E. coli & Staph aureus & K. pneumonia & Proteus mirabilis & \\
\hline Illiterate & 37 & 10 & 5 & 1 & 53 \\
\hline Count & 69.8 & 18.9 & 9.4 & 1.9 & 100.0 \\
\hline$\%$ within education & 27.4 & 24.4 & 14.7 & 4.2 & 22.6 \\
\hline $\begin{array}{l}\% \text { within bacteria } \\
\% \text { of total }\end{array}$ & 15.8 & 4.3 & 2.1 & 0.4 & 22.6 \\
\hline Primary & 23 & 3 & 2 & 3 & 31 \\
\hline Count & 74.2 & 9.7 & 6.5 & 9.7 & 100.0 \\
\hline$\%$ within education & 17.0 & 7.3 & 5.9 & 12.5 & 13.2 \\
\hline $\begin{array}{l}\% \text { within bacteria } \\
\% \text { of total }\end{array}$ & 9.8 & 1.3 & 0.9 & 1.3 & $13.2 \%$ \\
\hline Secondary & 15 & 4 & 7 & 7 & 33 \\
\hline Count & 45.5 & 12.1 & 21.2 & 21.2 & 100.0 \\
\hline$\%$ within education & 11.1 & 9.8 & 20.6 & 29.2 & 14.1 \\
\hline $\begin{array}{l}\% \text { within bacteria } \\
\% \text { of total }\end{array}$ & 6.4 & 1.7 & 3.0 & 3.0 & 14.1 \\
\hline $\begin{array}{l}\text { Diploma/ } \\
\text { B Sc }\end{array}$ & 60 & 24 & 20 & 13 & 117 \\
\hline Count & 51.3 & 20.5 & 17.1 & 11.1 & 100.0 \\
\hline$\%$ within education & 44.4 & 58.5 & 58.8 & 54.2 & 50.0 \\
\hline $\begin{array}{l}\% \text { within bacteria } \\
\% \text { of total }\end{array}$ & 25.6 & 10.3 & 8.5 & 5.6 & 50.0 \\
\hline Total & 135 & 41 & 34 & 24 & 234 \\
\hline Count & 57.7 & 17.5 & 14.5 & 10.3 & 100.0 \\
\hline$\%$ within education & 100.0 & 100.0 & 100.0 & 100.0 & 100.0 \\
\hline $\begin{array}{l}\% \text { within bacteria } \\
\% \text { of total }\end{array}$ & 57.7 & 17.5 & 14.5 & 10.3 & 100.0 \\
\hline
\end{tabular}

$\mathrm{Chi}=18.25, \mathrm{P}=0.032$

Table 7: Economic status influence on bacterial type

\begin{tabular}{|c|c|c|c|c|c|}
\hline \multirow[t]{2}{*}{ Economic status } & \multicolumn{4}{|c|}{ Bacteria } & \multirow[t]{2}{*}{ Tota } \\
\hline & E. coli & Staph aureus & K. pneumonia & $\begin{array}{l}\text { Proteus } \\
\text { mirabilis }\end{array}$ & \\
\hline \multicolumn{6}{|l|}{ Poor } \\
\hline Count & 19 & 0 & 2 & 0 & 21 \\
\hline$\%$ within econ status & 90.5 & 0.0 & 9.5 & 0.0 & 100.0 \\
\hline$\%$ within bacteria & 14.1 & 0.0 & 5.9 & 0.0 & 9.0 \\
\hline$\%$ of total & 8.1 & 0.0 & 0.9 & 0.0 & 9.0 \\
\hline \multicolumn{6}{|l|}{ Average } \\
\hline Count & 69 & 21 & 18 & 12 & 120 \\
\hline$\%$ within econ status & 57.5 & 17.5 & 15.0 & 10.0 & 100.0 \\
\hline$\%$ within bacteria & 51.1 & 51.2 & 52.9 & 50.0 & 51.3 \\
\hline$\%$ of total & 29.5 & 9.0 & 7.7 & 5.1 & 51.3 \\
\hline \multicolumn{6}{|l|}{ Good } \\
\hline Count & 44 & 19 & 12 & 11 & 86 \\
\hline$\%$ within econ status & 51.2 & $22.1 \%$ & 14.0 & 12.8 & 100.0 \\
\hline$\%$ within bacteria & 32.6 & 46.3 & 35.3 & 45.8 & 36.8 \\
\hline$\%$ of total & 18.8 & 8.1 & 5.1 & 4.7 & 36.8 \\
\hline \multicolumn{6}{|l|}{ Very good } \\
\hline Count & 3 & 1 & 2 & 1 & 7 \\
\hline$\%$ within econ status & 42.9 & 14.3 & 28.6 & 14.3 & 100.0 \\
\hline$\%$ within bacteria & 2.2 & 2.4 & 5.9 & 4.2 & 3.0 \\
\hline$\%$ of total & 1.3 & 0.4 & 0.9 & 0.4 & 3.0 \\
\hline \multicolumn{6}{|l|}{ Total } \\
\hline Count & 135 & 41 & 34 & 24 & 234 \\
\hline$\%$ within econ status & 57.7 & 17.5 & 14.5 & 10.3 & 100.0 \\
\hline$\%$ within bacteria & 100.0 & 100.0 & 100.0 & 100.0 & 100.0 \\
\hline$\%$ of total & 57.7 & 17.5 & 14.5 & 10.3 & 100.0 \\
\hline
\end{tabular}

Chi=13.72, $P>0.05$ 
Table 8: Hospital setting influence on bacterial type

\begin{tabular}{|c|c|c|c|c|c|}
\hline \multirow[t]{2}{*}{ Hospital setting } & \multicolumn{4}{|c|}{ Bacteria } & \multirow[t]{2}{*}{ Total } \\
\hline & E. coli & Staph aureus & K. pneumonia & Proteus mirabilis & \\
\hline \multicolumn{6}{|l|}{ Outpatient } \\
\hline Count & 100 & 29 & 26 & 17 & 172 \\
\hline$\%$ within setting & 58.1 & 16.9 & 15.1 & 9.9 & 100.0 \\
\hline$\%$ within bacteria & 74.1 & 70.7 & 76.5 & 70.8 & 73.5 \\
\hline$\%$ of total & 42.7 & 12.4 & 11.1 & 7.3 & 73.5 \\
\hline \multicolumn{6}{|l|}{ Inpatient } \\
\hline Count & 35 & 12 & 8 & 7 & 62 \\
\hline$\%$ within setting & 56.5 & 19.4 & 12.9 & 11.3 & 100.0 \\
\hline$\%$ within bacteria & 25.9 & 29.3 & 23.5 & 29.2 & 26.5 \\
\hline$\%$ of total & 15.0 & 5.1 & 3.4 & 3.0 & 26.5 \\
\hline \multicolumn{6}{|l|}{ Total } \\
\hline Count & 135 & 41 & 34 & 24 & 234 \\
\hline$\%$ within setting & 57.7 & 17.5 & 14.5 & 10.3 & 100.0 \\
\hline$\%$ within bacteria & 100.0 & 100.0 & 100.0 & 100.0 & 100.0 \\
\hline$\%$ of total & 57.7 & 17.5 & 14.5 & 10.3 & 100.0 \\
\hline
\end{tabular}

$\mathrm{Chi}=0.43, \mathrm{P}>0.05$

lower in women with history of operation for E. coli, Staphylococcus aureus, K. pneumonia and Proteus mirabilis. This low rate of isolation may be due to small size number of women with history of operation in our study cohort. Presumably, operation may be associated with increased incidence of UTI if the operation was on renal system or due to catheterization during the operation. History of catheterization was significantly associated with increased incidence of UTI [2, 19, 20], however, Emiru et al not found a significant association between UTI and history of catheterization [21].

There was a significant differences between the four isolated bacteria in relation to education level and this not consistent with that reported by others [19,21-24]. The predominant rate of isolation for the 4 bacteria was from women with higher education level, however, the lowest isolation rate was from women with secondary education level for E. coli, primary education level for Staphylococcus aureus and K. pneumonia, and illiterate (4.2\%) for Proteus mirabilis.

E. coli, Staphylococcus aureus, K. pneumonia and Proteus mirabilis were not significantly different in their isolation rates in relation to economic status, and hospital setting. This may be due to samples driven effect as 501 from 563 of the study population were from average and good economic level and most of the women included in this study were recruited from outpatient setting.

In conclusion, age, BMI, pus cells scale, and education levels were significantly associated with bacterial type.

\section{REFERENCES}

1. Baker SS, Alsamarai AGM, Mahmoud MI. Susceptibility of bacterial uropathogens to antimicrobial agents in Basrah. Med J Basrah Univ. 1988;7:73-81.

2. Vasudevan R. Urinary tract infection: an overview of the infection and the associated risk factors.J Microbiol Exp. 2014;1:00008.

3. Glover M, Moreira CG, Sperandio V, Zimmern P. Recurrent urinary tract infections in healthy and non-pregnant women. Urol Sci. 2014;25:1-8.

4. Alsamarai AGM, Latif IA, Abdulaziz MM. Antibiotic susceptibility of extended spectrum beta lactamase (ESBL) producing Escherichia coli. WJJPPS. 2016;5:195-215.

5. Alsamarai AGM, Ali S. Urinary tract infection in Female in Kirkuk city, Iraq: Causative agents and antibiogram. WJPPS. 2016;5:261-73.

6. Alsamarai AGM, Ali S. Urinary tract infections in female in Kirkuk, Iraq. Risk factors. WJPPS. 2016;5:180-95.

7. Alsamarai AGM. In vitro susceptibility of urinary bacterial isolates to gentamicin: six years study Med J Tikrit University. 1996;2:83-92.

8. Alsamarai AGM, Latif IA, Abdulaziz MM. Urinary tract infection in Iraq: Evaluation of early detection methods and etiology. WJPPS. 2016;5:181-94.

9. Chessbrough M. District Laboratories Manual for Tropical Countries. Cambridge University Press, Cambridge, 2004.

10. Amiri M, Lavasani Z, Norouzirad R, Najibpour R, Mohamadpour M, Nikpoor R, et al. Prevalence of urinary tract infection among pregnant women and its complications in their newborns during the birth in the hospitals of Dezful city, Iran, 2012-2013. Iran Red Cres Med J. 2015;17:e26946.

11. Salman ST, Noaman NG, Motib AS. Epidemiological study of symptomatic and asymptomatic bacteriuria among pregnant women attending antenatal clinic in Baquba - Diyala province. Diyala J Med. 2013;4:79-86.

12. Njunda LA, Assob JC, Nsagha SD, Nde PF, Kamga HLF, Nkume AF, et al. Uropathogens from diabetic patients with asymptomatic bacteriuria and urinary tract infections. Scientific J Microbiol. 2012;1:141-6.

13. Raz R. Urinary tract infections in postmenopausal women. Korean J Urol. 2011;52:801-8.

14. Okonko IO, Ijandipe LA, Ilusanya OA. Incidence of Urinary Tract Infection (UTI) among Pregnant Women in Ibadan, South-Western Nigeria. African J Biotechnol. 2009;8:6649-57.

15. Haider $G$, Zehra N, Afroze A. Risk factors of urinary tract infection in pregnancy. J Pak Med Assoc. 2010;60:213-6. 


\section{www.odermatol.com}

16. Amiri FN, Rooshan MH, Ahmady MH. Hygiene practices and sexual activity associated with urinary tract infection in pregnant women. East Med Health J. 2009;15:104-10.

17. Kolawole AS, Kolawole OM, Kandaki YT. Prevalence of UTI among patients attending Dalhatu Araf Specialist Hospital, Lafia, Nasarawa State, Nigeria. Int J Med Sci. 2009;1:163-7.

18. Hooton TM, Schools D, Hughes JP, Winter C, Roberts PL, Stapleton AE, et al. Prospective study of risk factors for symptomatic urinary tract infection in young women. New Eng J Med. 1996;335:468-74.

19. Alemu A, Moges F, Shifraw Y, Tafess K, Kassu A, Anagaw B, et al. Bacterial profile and drug susceptibility pattern of urinary tract infection in pregnant women at university of Gondar teaching hospital, Northwest Ethiopia. BMC Res Notes. 2012;5:197.

20. Moges F, Mengisto G, Genetu A. Multiple drug resistance in urinary pathogens at Gondar College of Medical Sciences Hospital, Ethiopia. East Africa Med J. 2002;79:415-9.

21. Emiru T, Beyene G, Tsegaye W, Melaku S. Associated risk factors of urinary tract infection among pregnant women at Felefe Hiwot referral hospital, Bahir Dar, North West Ethiopia. MBC Res Notes. 2013;6:292.

22. Masinde A, Gumodoha B, Kilonzo A. Prevalence of urinary tract infection among women at Bugando Medical Centre, Mwanza, Tanzania. Tanzania J Health Res. 2009;11:154-9.

23. Hazhir S. Asymptomatic bacteriuria in pregnant women. Urol J (Tehran). 2007;4:24- 7.

24. Sheikh MA, Khan MS, Khatoom A. Incidence of urinary tract infection during pregnancy. East Med Health J. 2000;6:265-71.

Copyright by Abdulghani Mohamed Alsamarai, et al. This is an openaccess article distributed under the terms of the Creative Commons Attribution License, which permits unrestricted use, distribution, and reproduction in any medium, provided the original author and source are credited.

Source of Support: Nil, Conflict of Interest: None declared. 